ACADEMIA PAPERS 


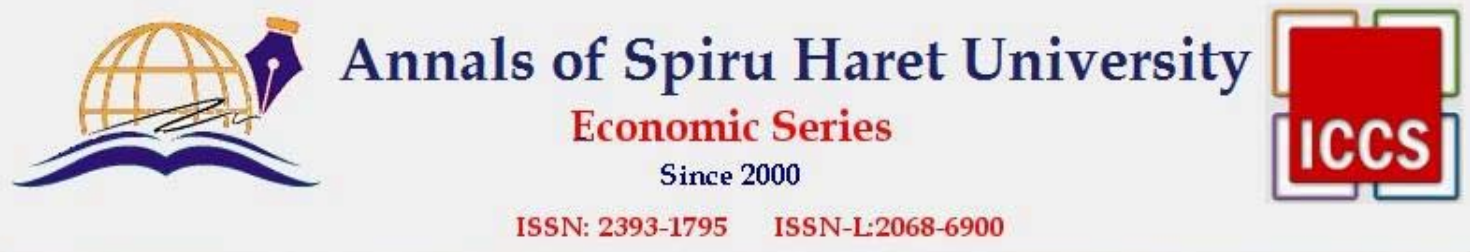

Issue 2/2016

\title{
ABOUT THE DISCIPLINARY CONTENT OF DOXASTIC MANAGEMENT
}

\author{
Ioan GÂF-DEAC ${ }^{1,3}$, Cristina Monica VALECA ${ }^{2}$, Ioan I. GÂF-DEAC ${ }^{1}$, \\ Mihaela PÎRVULESC ${ }^{3}$, Ioana Andreea MARINESCU ${ }^{1}$, \\ Lăcrămioara Rodica HURLOIU ${ }^{1}$ \\ 1 "Spiru Haret" University, Ion Ghica Street, no. 13, Bucharest, 030045, \\ Romania, Tel.: +40214551000, Fax: +40213143900 \\ ${ }^{2}$ University of Pitesti, Targul din Vale Street, no. 1, Pitesti, 110040, \\ Romania, Tel.: +40348453102 Fax: +40348453123 \\ ${ }^{3}$ Bioterra University, Garlei Street, no. 81, Bucharest, 013722, Romania, \\ Tel.: +40214906129, Fax: +40212693438, \\ Email:ro_affairs@yahoo.com,monica.valeca@nuclear.ro, \\ editurafmp@gmail.com,m_pirvulescu@yahoo.com, \\ andreea_marinescu1975@yahoo.com, hlacra@yahoo.com
}

\begin{abstract}
The article states, in substance, that by accepting the hypothesis of the continuous transformation of content and configuration of the "small worlds", along with developments in technology and behavioural sciences, necessarily is accepted the finding that endo-exogenous mutations influence the organizational entity as a whole, with notable consequences on management. Doxastic management is an epistemological novelty, covered by the scientific copyright since 2013. It appears that is not yet discerned the neighbourhood structure between model, physical reality and metaphysical reality. It is also considered that on the infinite/finite segment (physical reality-model) the sitting of management is possible, operating doxastically, through new emphases placed on the iterative idealization of the expected / aspired horizon. Etymological explanatory aspects on doxastic are narrated and it is believed that the global management is the conceptual depositary of the doxastic management. There are described
\end{abstract}




\section{Annals of Spiru Haret University \\ Economic Series \\ Since 2000}

ISSN: 2393-1795 ISSN-L:2068-6900

Issue 2/2016

elements that define the managerial complexity in terms of using new information technologies, early conceptual shaping of doxastic management and the explanatory formulas for the disciplinary content of the doxastic management reflected in the doxometric conceptual premises in management.

Key words: doxastic management; metaphysical reality; doxometric concepts in management; global management; neighbourhood structure.

JEL Classification: M10, M14, M20, M50

\section{Introduction}

Doxastic management is an epistemological novelty, covered by the scientific copyright since 2013 [Gâf-Deac, 2013]. We must keep in mind the fact that the managerial practices by which flawed ideational processing in organizing and management would be mastered are not yet properly systematized.

Experiences from different variants/versions of managerial reality are not yet systemically exploited. The real direction that the company is advancing represents the real essence of leadership. Or, precisely this directioning needs meta-management and managerial doxastic in order to be perceived, assumed, legitimated. Managerial illusions and disillusions directionally can come from anywhere and they cannot be circumvented. We believe that, in fact, leadership can act against them, but using quasidiscrete acts of doxastic managerial influence. Changing belief in doxastic management may be irreversible when introspection is positive.

Reviewing conviction for change is not necessary in the decision making process, but the expected success follows the road adjusted with such quasi-continuous transformations.

It is considered that a conviction state is obtained that does not require any more changes when the managerial access is closed / limited to any agent from crowd of intelligent multi-agents that can no longer produce influences or suggest new transformations. 

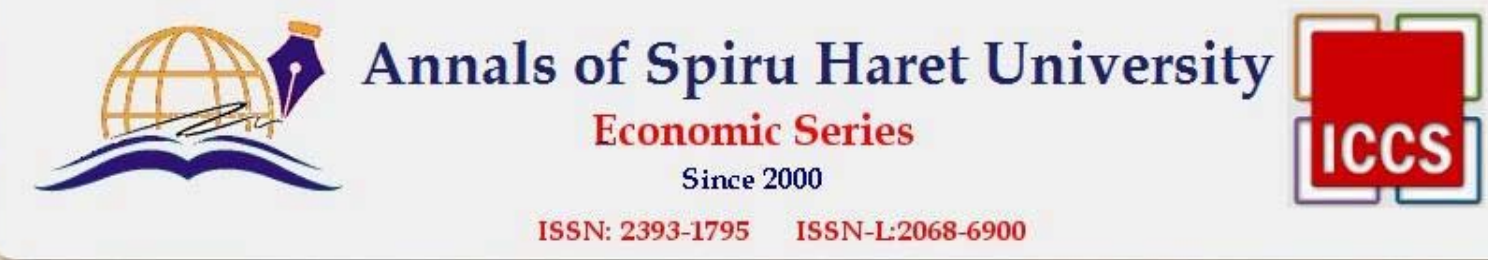

Issue 2/2016

The attempt to state the result $(\Delta)$ imposes on the manager the commitment in changing the belief. The trust/conviction current assumed by the manager, once stabilized it is apt for its widespread use.

\section{Explanatory Etymological Issues on Doxastic}

Doxology (doxology, doxologies) in direct, concrete acceptance refers to an "anthem" or a "verse" in the Christian liturgy, in order to glorify God. In Greek, the term dóxa can also have the meaning of opinion.

Therefore, doxastic may be related to personal opinions, in the context of discussions regarding their susceptibility to deeper interpretations of the faith/trust. The extension of the meaning of the term dóxa is also that of suggestive opinion, idea.

Its etymology is from the Latin doxologia or doxa, marking the meaning of estimation, glorification, prayer (oration), to which logo is added, meaning speech, utterance into something to be believed in, believable. Doxastic is closely related to trust or faith. Being doxastic signifies commitment in predisposition or disposition to believe, with extensions in sufficient states of faith or trust through judgments, opinions, desires, wishes, requests.

On the other hand, the term doksei means "retain", "believe" and "support". However, dóxa points to opinion as a term which does not express the total, ideal, perfect clarity. This way, incipiently appears "the logic of opinion", thus the doxastic expression of what is believed.

Doxastic logic is part of the modal logic of trust and distrust. More generally, the logic of trust is that part of logic dealing with "the generic trust". The truth of the managerial opinion is not similar to its fundamental truth. [Gâf-Deac, 2013]

Explanatory Dictionary of the Romanian Language [DEX online, 1998] presents the following explanation for the word doxology "liturgical chant dedicated to the Holy Trinity." The origin of the word comes, according to the same sources, from "doxa" = glory and "logos" = speech. In another perspective, closer to organization and management, the explanation for doxology occurs as "systematic study of the role appreciation has in school education". In liturgical essence, doxology is the glorifying form of expressing transcendence, namely divinity's power and majesty, hence of the truth in the act of praying, of the liturgical worship. 


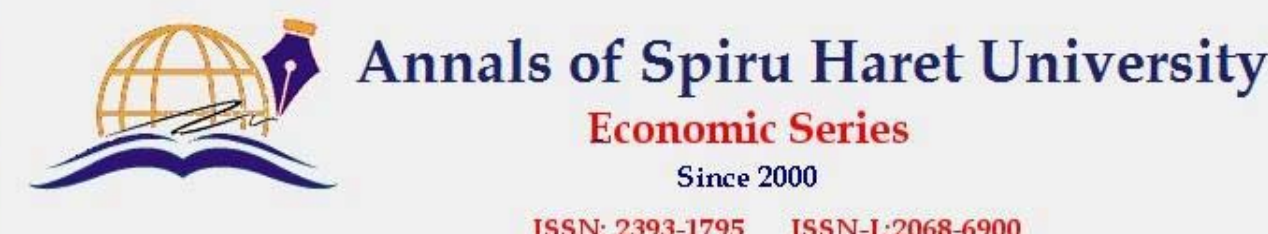

ISSN: 2393-1795 ISSN-L:2068-6900

Issue 2/2016

One can make distinctions between "doxastic" and "sub-doxastic" states, which in their turn determine in man the recording of the "personal" and "sub-personal" states, respectively the absolute faith/self-awareness, differentiated from the intermediate state of search using thinking in order to reach the absolute self-awareness.

The iconic example of the doxastic state can be given by examining the cut down tree trunk circles. In essence, the number of circles can provide information about the age of that tree (the doxastic state), but does not highlight the state of full/absolute confidence that this age has the respective, complete, final significance (the sub-doxastic state). Confidence, in the context of proximity with doxastic, highlights a statement, a belief referring to faith in a content of a sentence that it is known and expected/followed with certainty (is "considered" with certainty). Perception of knowledge in itself becomes awareness/knowledge.

On the other hand, doxology/...gies, according to the dictionary [The Merriam-Webster Dictionary, 2004], usually signifies the action of uttering in faith of "short hymn of praise to God". At the human actional level, through such an approach is foreseen a "request of confidence", search or address towards trust, respectively conviction towards God, being launched a certain "substance of faith", in faith and knowledge.

By similarity, on the human perceptive level is advanced the concern for knowledge on deeper and deeper horizons, to prove belief in organization and management. It is about the trend of "idealizing the models" formalized in the area of organizing and managing the life and aspirations to the limit of metaphysics. Beyond the perceptible virtual horizon there is a different philosophy, namely "other knowledge".

It is not yet discerned the neighbouring structure between model, physical reality and metaphysical reality. We believe that on the infinite/finite segment (physical reality-model) the sitting of management is possible, operating doxastically, through new emphases placed on the iterative idealization of the expected/aspired horizon. Quasi-complete objectification of the managerial decisions can be obtained by iterations and reiterations as long as certainty in only detectable from the construction of finite, quasi-infinitesimal elements. 

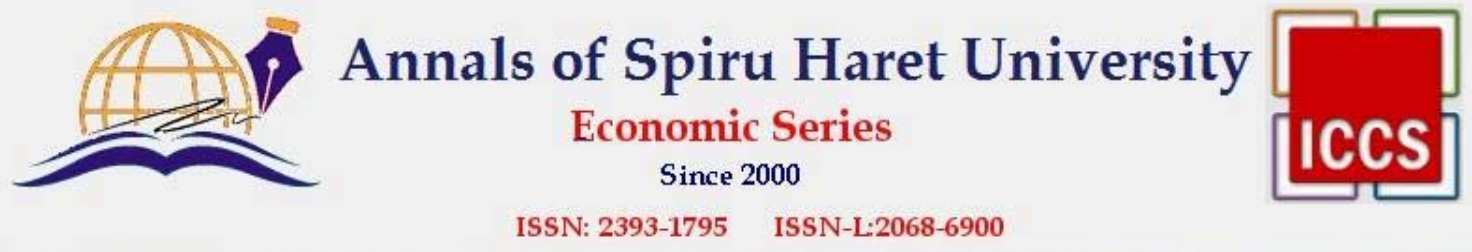

Issue 2/2016

Such a vision in the field of management is advanced through the following lines in original formula, for the first time, relying on the conceptual refinement that pervades the environment, economic and socialproductive, classified as generally systemic, corresponding to the beginning of the $21^{\text {st }}$ century.

Omniscient logic (omni-scientific), in the present work, is procedurally considered "the infinite logical understanding" through the advanced iterative perception of knowledge used in organization and management. Escalated informational substance becomes in itself knowingness, meaning information within the meaning of perceived composite. For that matter, the perception of understanding is ultimately linked to the "logic of the infinite understanding." [Cozic, 2004]

Having the perception of knowledge means commitment to the conventional and metaphysical informational immersion. In the meaning, comprehensible or inside doxastic knowledge means "in knowingness" or simply "informed". Epistemic limitation, in fact, agrees the formalization, respectively the "markable/marked zoning" of knowledge. In such a perspective, formalized rationality operates between the limits/borders/boundaries consenting the spring/source of knowledge.

\section{Global Management - Conceptual Repository of Doxastic Management}

Accepting the assumption of the continuous transformation of the content and configuration of the "small worlds", along with the evolutions of the behavioural technologies and sciences, necessarily is accepted the ascertainment that endo-exogenous mutations influence the organizational entity as a whole, with noticeable consequences on management. [Kocken, 1989]

At the same time, among technologies there is a more pronounced and visible quasi-infinitesimal coherence. Technologies are about to link sciences. Productive endeavours, hence the purely empirical managerial ones as well are in decline. 


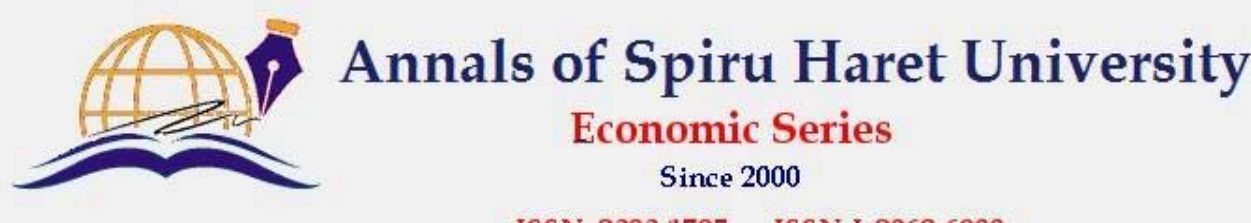

ISSN: 2393-1795 ISSN-L:2068-6900

Issue 2/2016

The technological and managerial dimensions of the crises (difficulties) through which the enterprises go gradually, or generalized, appear as global factors of study and interpretation.

Technological and managerial transformations cannot be considered an amount of minor constraints that could be solved by the simple acquisition of a physical system of performant equipment and machinery, or through the artificial introducing of some theoretic management methods. Reducing settlement only to the exclusive introduction of computerization is also inappropriate and frequently ineffective when applied "in itself", unilateral/unidirectional.

There is a permanent contradiction between strong productivity growth (from tangible/classical technological and managerial sources) and the insufficient regeneration of demand, which may lead in different time intervals to an under-functioning of an entity's economy. It is time to bring added value management, relying on knowledge, on intangible/of innovative rupture technological and managerial sources.

\section{Managerial Complexity in Terms of Using New Information Technologies}

New informational technologies alongside the results from the behavioural sciences, in general, presents the following main managerial consequences, together with their advent and application: the introduction in the productive-industrial processes of some new technical processes and methods, with different parameters, superior to the existing ones; the emergence of new objects: products and services with increased degree of novelty; the emergence of new chains of transformation of knowledge, matters and materials which enter the technological process. [Gâf-Deac, 2011]

The new technologies form a family with items that, individually - in a certain time interval - dominates through competitiveness the knowledge and productive-industrial processes through: complexity; is the ability of a system to go through a large number of distinct states in a short time interval; machines are noncomplex systems, hence trivial, as they have a predefined, predictable behaviour; the ecological and social systems are complex, hence nontrivial, because their concrete behaviour at a specific time is not predictable. 
Instead, the diversification of technological change leads to a specific complexity in the industrial-productive systems. The type of sources, the range of needs, the technical expertise of the enterprises require new methods of action through "novelties". The technology complexity can be managed, because the programming of the actions of the machines from the transformation flows denote the tendency of obtaining the desired results as precisely as possible. A bad management, the lack of rules or their missimplementation (or limited implementation) determine the apparent technological complexity. [Gâf-Deac, 2011]

The complexity of the classic industrial-productive processes is increasing, as within the general economic environment information, hence knowledge, and reactions over which hovers a constant uncertainty about their validity circulate.

\section{The Incipient Conceptual Shaping of the Doxastic Management}

Doxology management is the form of confirmation, validation, legitimation, including laudatory assessment, in comparable or competitive terms of the organization and management's transcendence. The power and all-representativeness of a managerial structure functional in the complex act of organizing and managing is felt/anticipated. In other words, there could even be a managerial worship (the cult of organization and management), which is above the results, solutions, techniques, procedures, methods etc. of organization and management offered by the current, ordinary, trivial management science. [Gâf-Deac, 2013]

Equally, "telling the word" (doxa and logos) can be a complex of proposal, statement, which in management initially presents itself as being self-contradictory. In reality, whatever telling expresses a truth, conventionally desirable, acceptable or undesirable or unacceptable.

The apparent non-contradictory character of "telling", meaning the assuming by the manager of a meta-procedural future image (above the techniques and methods of management) is found in "notice" or "statement" expressed contrary to the generally accepted opinion about a certain "organization and management". An assumed managerial statement can be contradictory solely in terms of its openness to objections. 


\section{ \\ Annals of Spiru Haret University \\ Economic Series \\ Since 2000}

ISSN: 2393-1795 ISSN-L:2068-6900

Issue 2/2016

The managerial incredible is immediately contrary to the expectations. For example, para-managerial, non-managerial, etc. come together as meta-managerial formalizing elements. In such an approach it is possible the acceptance of proposals as being true, but which would be false for the organization and management through the self-contradictory contained by default. An approach, respectively an engagement to use the proposals that we believe as being true falls into doxastic management and organization.

However, it can be said that manager's simple belief/entrustment regarding some truths declaratively arising from certain sentences of his of meta-managerial style is not strictly necessary to lead to contradictions. We are accustomed to ante-paradoxes related to managerial decisions, which are spotted and mastered. In managerial doxology, the strict necessity of the preliminary argumentations is disregarded. Thus we witness a certain "liberalization of management", to it taking out under the shackles of methods and techniques of organization and management.

Management is not and should not be above reality, namely to "the dominator", "the leader" or "the dominance" over the processes, phenomena, objects. [Gâf-Deac, 2011] $\mathrm{He}$ is and must remain the instrument more and more free, flexible, adaptable and catalyser for carrying on certain alignments of the processes, phenomena, objects to attain certain states thereof from which to extract (to delimitate) results.

\section{Elements of Meta-management for Doxastic Interrelationships}

Meta-management aims faith, belief, opinions, conception, and confidence. Returning from traditional teachings is happening in order to obtain the tangency with the certainty from known words and meanings of the formalized life organized and conducted in the ordinary world. The (manager's) human mind believes or manifests trust in a process, phenomenon, person or object when induces organization and management.

Managerial faith is a conviction regarding the truth that refers to certain states of the organized and managed reality. The examination of some signs, evidence etc. from the contextual content of the conditions or the situations related to the processes, phenomena, objects etc. leads to 

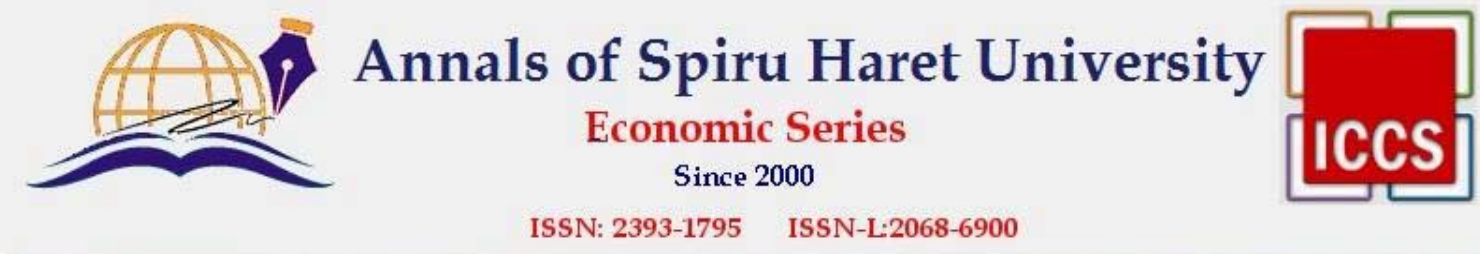

Issue 2/2016

managerial acceptance or acceptation. After all, a pseudo-certainty or quasicertainty among the one who believes (the manager) is seen. As a matter of fact, among managers, we find the feeling that in a certain organization and management formula of organization and management there is always "some" truth, in the conventional sense. [Gâf-Deac, 2014]

Thus, a sentence, a statement, the acceptation of a fact of organization and management, an assertion, etc. may, one by one or together, be true, without the immediate personal knowledge of the concerned condition/situation.

In meta-management and in doxastic management we meet the partial insurance, without absolute positive knowledge and without the complete certainty of the road towards targeted results. Persuasion, conviction, confidence, etc., they all participate in justifying empirical knowledge in management.

\section{Doxometric Conceptual Premises in Management}

The different situations that reflect the realities between the conventional variables from the conventional environment are also to be found in doxastice conceptual expressions. In practice, requirements targeting the need to identify the relative size of the parameters between the meta-management variables occur frequently. [Gâf-Deac, 2008]

At the same time, the theoretical aspects stated or formulated in a particular content should be tested so as in a next, immediate stage, the confirmed relations to be used for qualitative and quantitative predictions in a so-called doxometry. (Figure 1) [Gaf-Deac, 2013]

By analogy, Samuelson, P.A. (1954) shows, for example, that econometrics is "the application of mathematical statistics to provide empirical support for the models built using mathematical economics and to provide numerical estimates." Mathematics, statistics and economics in their composed interference give econometrics a complex attribute, mainly being the quantitative study of the micro or macroeconomic reality. In the wider sense, in management, doxometry gives the significant enlargement/wideness of the problematic of organizing and management, respectively the vision on the extreme limits for the actions of measuring the organization and management that may be of decisional interest. 

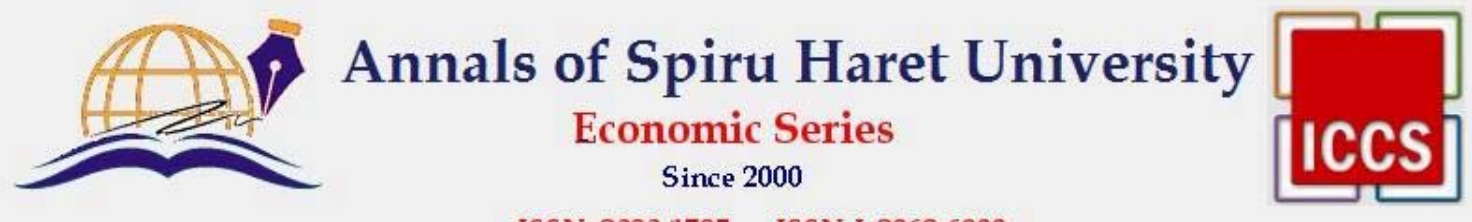

ISSN: 2393-1795 ISSN-L:2068-6900

Issue 2/2016

Doxometrics' object, scope and methods are subordinated to the derivation of the complex systems, respectively to establishing the decisional elements for behaviour management (Figure 2). [Gaf-Deac, 2013]

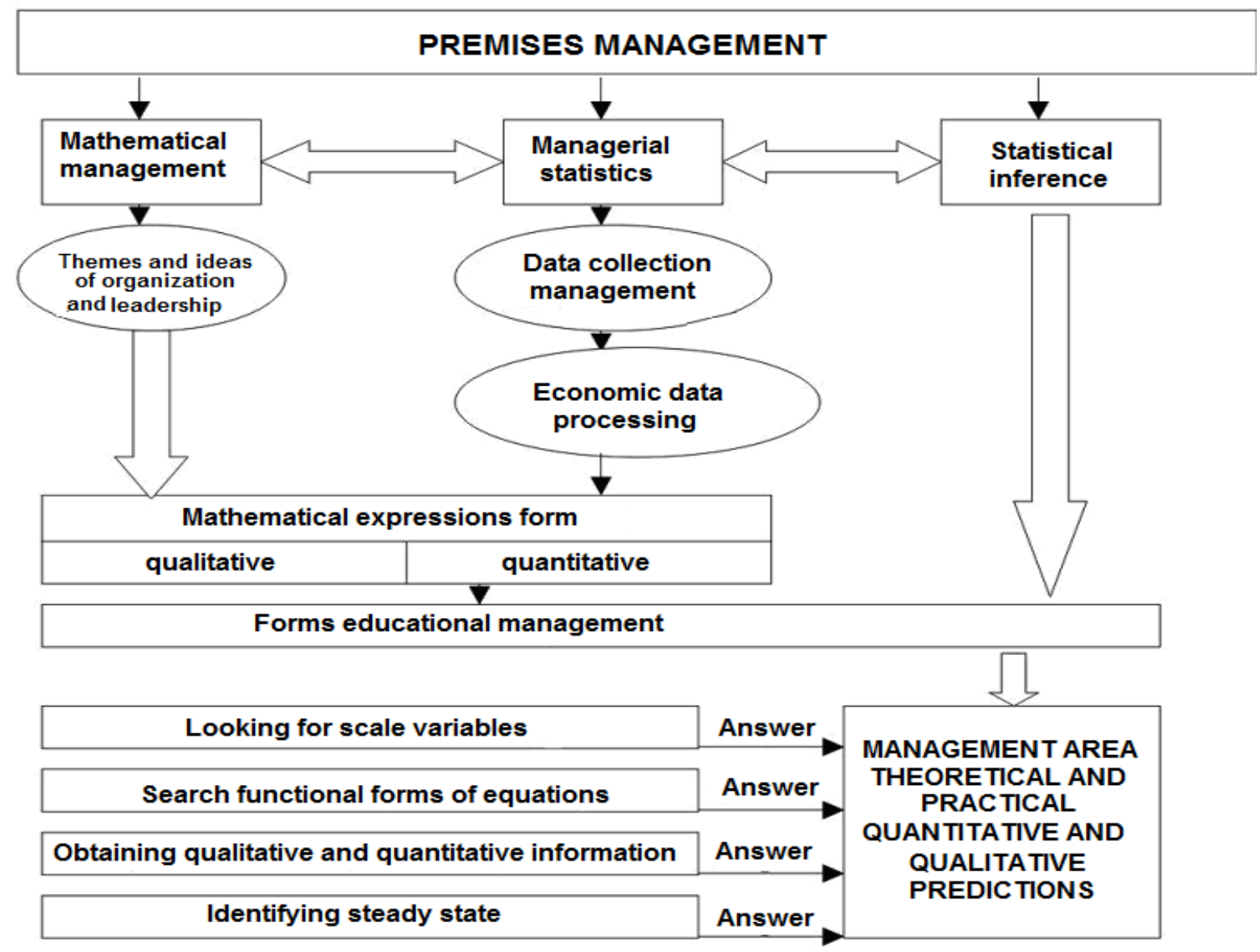

Figure no. 1. Premises for the formalization of the managerial doxometry as qualitative and quantitative predictive area

Source: Gâf-Deac, I., Bazele managementului doxastic, FMP, București, 2013

The records of the primary managerial levels are followed by intuitive evaluations, seeking the connections between the content and the value of the data derived from observations and those of the dimensions and qualities measured through modelling for organization and management. 

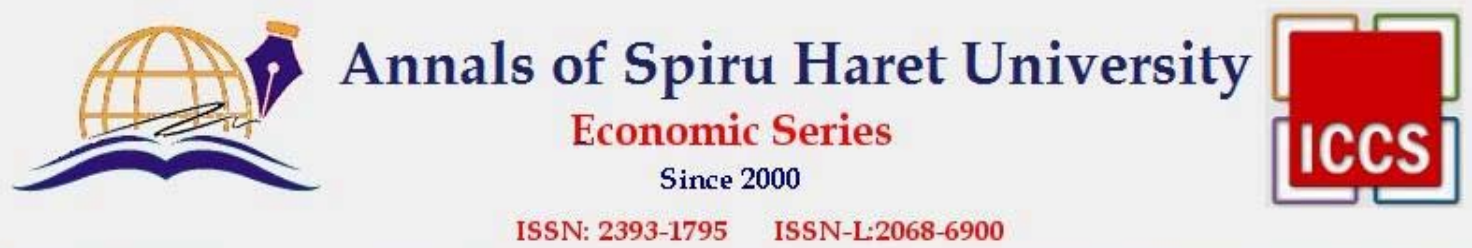

Issue 2/2016

Thus, in the general context, for management, we identify real structural relationships on causal, deterministic bases. [Gâf-Deac, 2008]

Some values from a range delimited by dimensions and qualities of organization and management are probabilistically determined by previous values.

Unravelling the mechanisms of transforming the variables between them one can specify the functional relationships associated to the real structure of the studied managerial process or phenomenon.

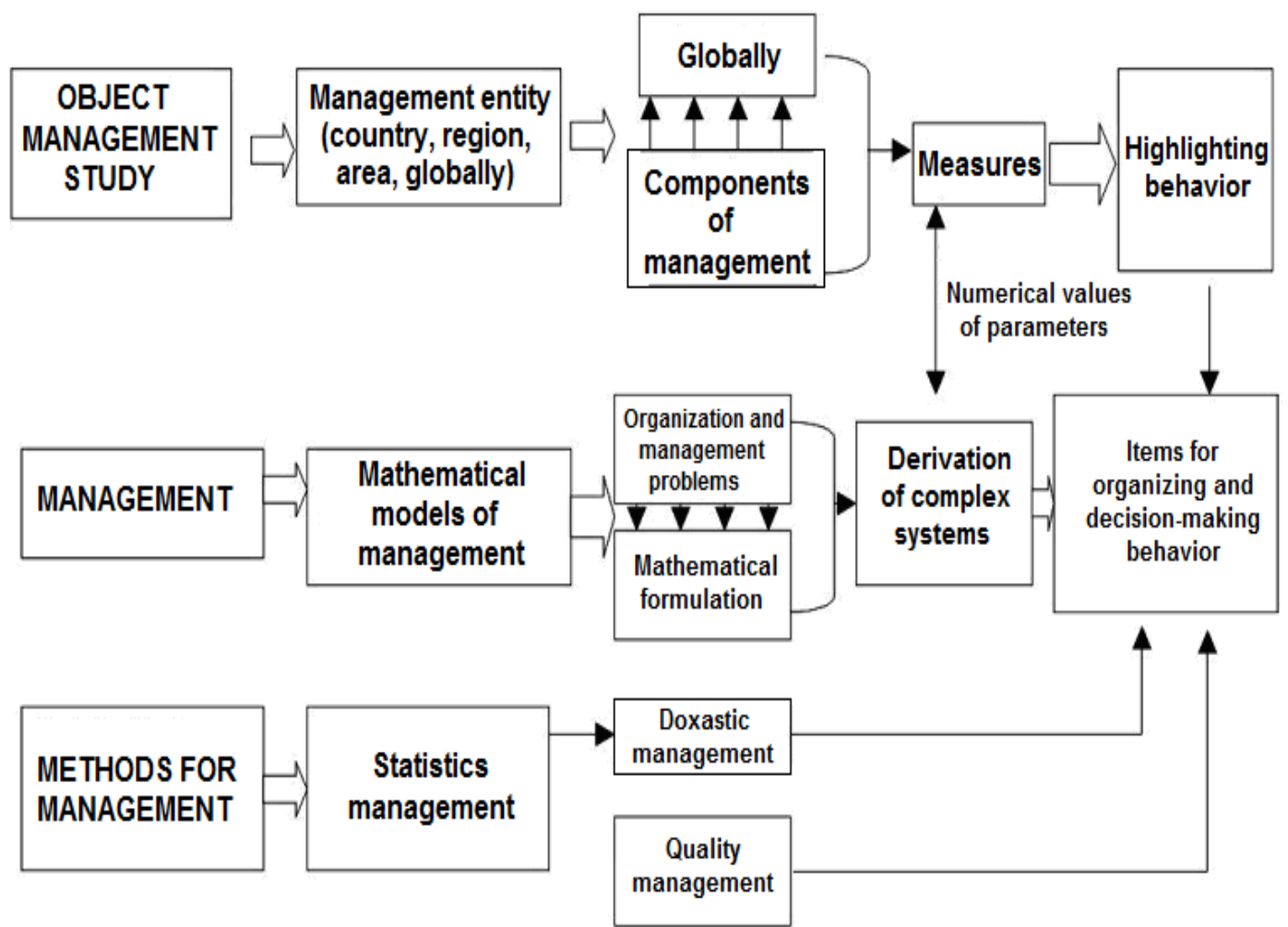

Figure no. 2. The object, scope and methods of managerial doxometry

Source: Gâf-Deac, I., Bazele managementului doxastic, FMP, București, 2013

Highlighting the way and the form under which one variable affects another variable represents the endeavour of exposing the actionable complexity, respectively of research the organization and management. 

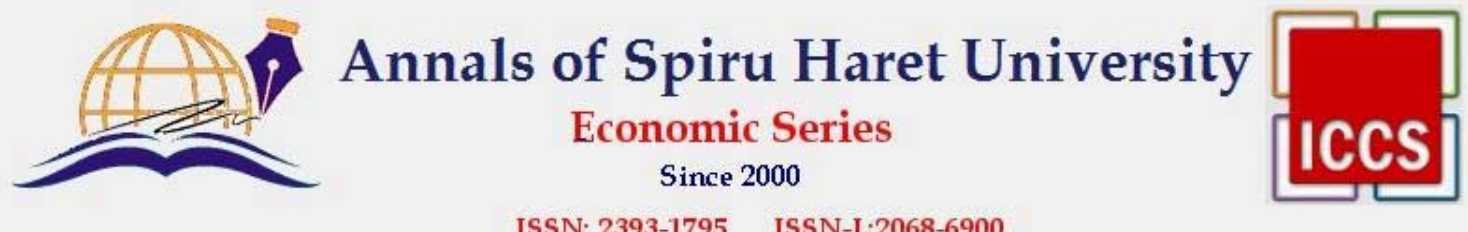

ISSN: 2393-1795 ISSN-L:2068-6900

\section{Issue 2/2016}

Usually, the reduction as much as possible of the research to the managerial relationship linear in form is aimed.

The mechanism of managerial transformation is decomposed through doxometric enterprises until obtaining the sets of data considered to be true, then it is proved the maximum verisimilitude of organization and management.

Between the managerial reality and the imagistic model, of "cliche" type at a given time for organizing and managing a certain isomorphism is recorded, in the contents of which remain contradictions between: 1) researched structure and managerial process; 2) stochastic causes and manifestations, and between 3) organizing and managing empirical and actual-rational statements. [Gâf-Deac, 2004]

The above finding marks the differences between doxometry and mathematized management, respectively between phenomenology's quantitative, empirical approach and statistics of organizing and managing problem, namely the rational research of the organization / management structure and the causes of the general managerial problem.

In itself, doxometry, through the fact that "measures", hence induces credible quantifications of information, determines "knowledge about organization and management" in the general, cognitive sense. From a rational model it is possible to build, hence to generate, an empirical model which "pushes" managerial knowledge into new evolutionary areas using results-images (Figure 3). [Gâf-Deac, 2013]

Doxometric models reconstruct the managerial mechanisms in images, which, under statistical processing, lead to new results-images, useful to the credible management of complex systems' behaviour.

The models of the credible organizing and managing possibilities are generated by specific statistics, with the help of which the entire set of alternative models of management is tested until establishing the one with the maximum plausibility. Statistics are the main inputs into the investigated management processes. Reducibility may affect prediction to the extent to which concentration or the simplifications operated by statistical calculations lose some of the variable calculations with permanent potential of influencing the organization and management's credibility. [Gâf-Deac, 2003] 

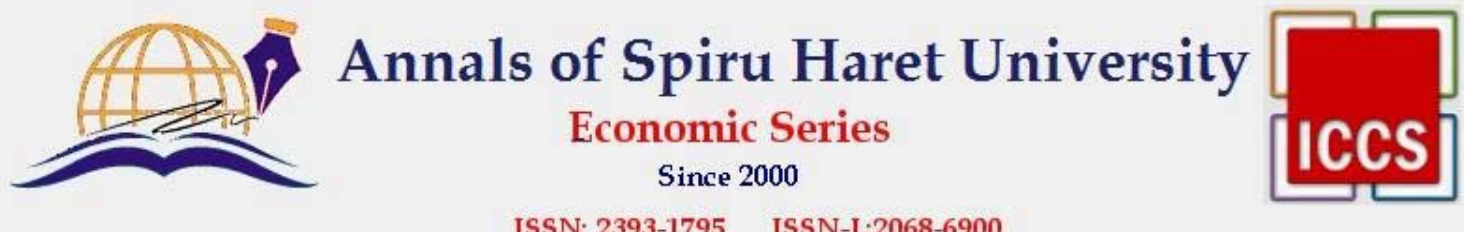

ISSN: 2393-1795 ISSN-L:2068-6900

Issue 2/2016

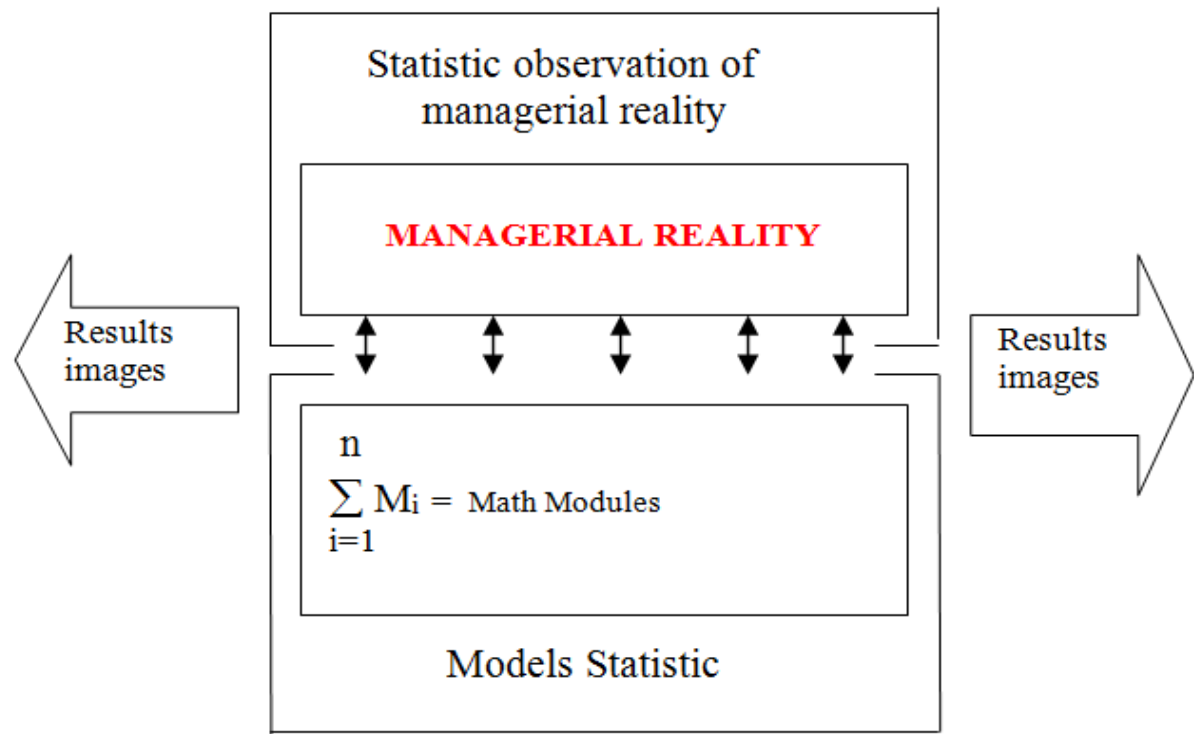

Figure no. 3. Getting results-images usable for modifying complex systems of organization and management

Source: Gâf-Deac, I., Bazele managementului doxastic, FMP, Bucureşti, 2013

In fact, doxometry represents an imagistic extension or a further credible development of mathematized organization and management, never characterized by ideal credibility. Between micro and macro-management dimensional relations are marked, respectively a non-contradictory dualism is formalized. The applicability of the doxometric models is tracked through resultimages, simultaneously in the two levels, namely micro and macro-managerial.

Doxometric adjusting and, equally, estimating credibility represent searching procedures or instruments of the prediction alignments with higher degree of plausibility in organization and management. Simplifying assumptions should not influence the growth trend of identifying managerial plausibility.

The Framework for Interpreting the Doxastic Managerial Phenomenon

In the systemic theory the system is defined as "a complex of interacting elements". Within the system identified in the immediate, visible rationality, interaction is guided by scientific/quasi-scientific principles 


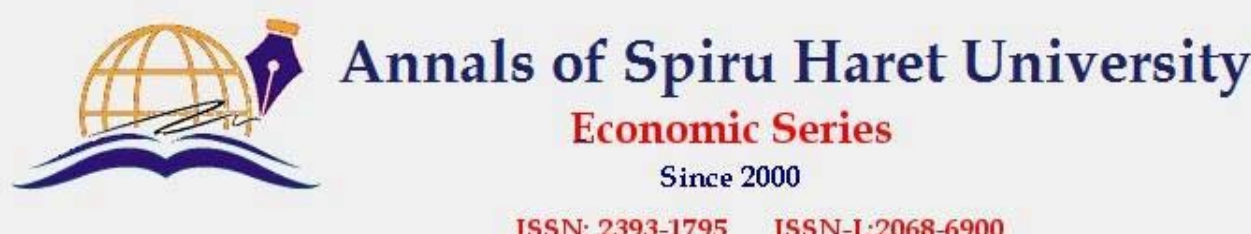

ISSN: 2393-1795 ISSN-L:2068-6900

\section{Issue 2/2016}

which arranges and determines, ordinarily, the assembly to have the tendency of continuously improving its activity. For scientific and practical purposes, the system is defined as such: "it is a group, an integrate, an assembly of natural and artificial elements that generate common goals (a common goal unites them)." [Gâf-Deac, 2005]

The social organization's system is the most complex category of system and within it the phenomenon of leadership occurs. To identify the defining elements of a doxastic managerial system it is used a broader definition of the system, which is considered to be an organized assembly, a class of phenomena which satisfy the following requirements: to be able to specify a set, an amount of identifiable reliable elements; to exist identifiable relationships of trust between at least some of them; certain trust relationships should involve other relationships (infinite chain of relationships); a complex of trust relationships at a given time involves a certain complex at a next time, aspect that highlights the dynamics of the system.

Structurally, systems refer to the reunion of the specific parties, among which are listed:

a) Components of doxastic system. These are represented by elements and connections. The element is a quality (an object, a process, "something") from of a phenomenon, a feeling, a confidence etc. which is regarded as a part not subjected to the analysis. Elements establish the quasi-limits of the infinite from any concrete or beyond the screen that opens the metaphysical space and time.

b) Relations of the doxastic managerial system with the exterior environment. In relation to the environment, the doxastic managerial system appears as an inclusion and has at least an input, an output, a behaviour and a function that refers to confidence, conviction, good conventionality of an organization and/or leadership's acceptance.

The concept of inclusion means that any system can fit into a larger reliable structure. The limits of a doxastic managerial system are relative, even more relative than those of the trivial managerial system because confidence is reflected in a referential system of relativity accentuated by quantitative and qualitative possibilities. [Gâf-Deac, 2002] 
c) Characteristics and principles of doxastic managerial systems' functioning. The command value is the credibility/conviction task that the doxastic managerial system has to solve as organized higher assembly, in an environment that produces credibility disturbances. Adaptability is the attribute of keeping unchanged confidence's command value at the output in a disruptive environment. Adaptive doxastic managerial system operates on the principle of the relative independence of a trust's output in relation to credibility input as outstanding value. The input-output relation in adaptive doxastic managerial systems cannot be explained only by the linear causality of the classical vision but resides in a specific causality of confidence, being understood through the concept of stability.

In doxastic management control may be considered doxastic feedback. The regulator is connected with the input and the output. Following the reverse connection, it intervenes on the general state of the doxastic managerial system (it realizes direct interventions on the confidence input and on the system's status).

d) Other operating and behaviour characteristics. Orientation is the attribute of the doxastic managerial system of improving its level of responses under various disturbances of confidence/conviction.

The set of links of the general-doxastic system with the external environment is performed using material, energy and information flows. [Gâf-Deac \& Roşca, 2014]

Any entity is characterized by the inputs represented by the relations with other providing entities and outputs as relations with beneficiary units (Figure 4). [Gaf-Deac, 2013]

To carry out its specific functions, the entity is equipped with the necessary managerial means, has an operational status and a command value determined by its own plan. The leading subsystem connects to the driven subsystem through the informational connection subsystem.

Achieving the command value as a sub-process reaches with flow of information (feed-back) to the decision-makers. They make decisions regarding the adjusting of the doxastic managerial subsystem, which they transmit to the factors that modify their action, meta-managerially transforming the input value. 

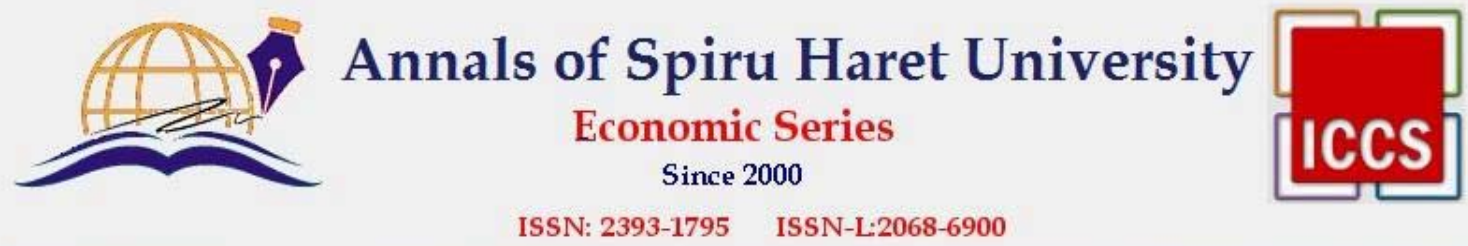

Issue 2/2016

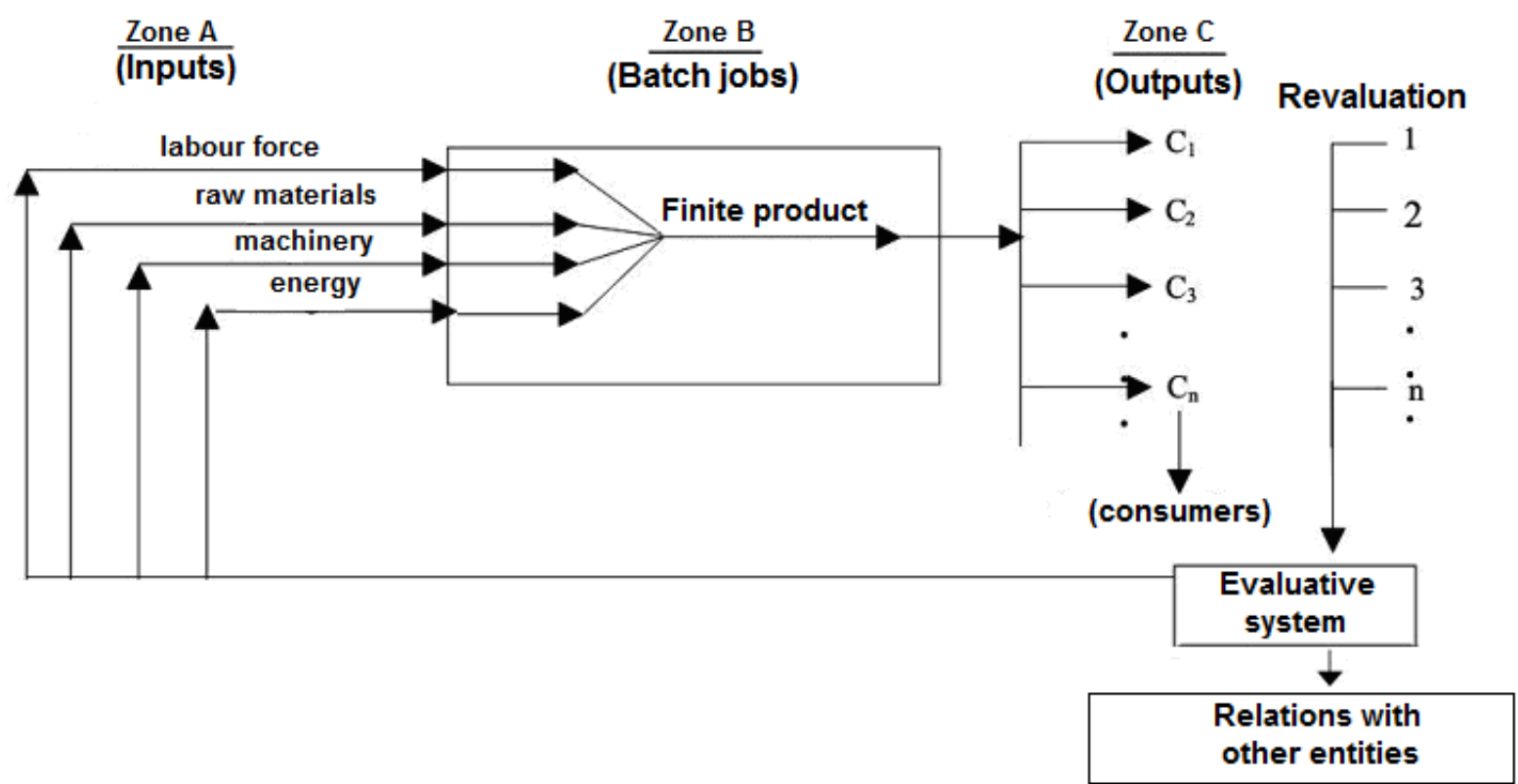

Figure no. 4. The inputs-processing (transformation)-outputs algorithm in the doxastic managerial system

Source: Gâf-Deac, I., Bazele managementului doxastic, FMP, Bucureşti, 2013

\section{Doxastic Managerial Behaviour}

For a superstable behaviour, the manager operates the internal control circuit which manages to attract in solving the problems that arise in the functioning process, the internal capacities of inventiveness and initiative. [Gâf-Deac, 2007]

As an example, the compound general behaviour of the company and the manager is superstable, aiming at achieving the function of the company, independent of the multiple relationships with the external environment, of both the company and the manager.

This superstability takes place by opening the internal control circuit in order to request the means of establishing the equilibrium; the company and the manager have double adjustment possibilities, but they are truly effective only when they manifest as superstable.

The adjustment-compensation intervention is necessary in some periods precisely because of the derived interactive place the manager holds within the general doxastic managerial system. 
The concept of doxastic system helps understand the idea that the managerial process aims to appropriate the organization of the doxastic managerial system to the real life.

The essential aspects of the confidence building process are those of obtaining the doxastic managerial information and using it to enable the development of some specific evolutions of organization, regulation, stabilization, work implementation in an efficient manner of the capabilities of complex elements.

The concept of doxastic managerial system allows the highlighting of the factors contributing to the meta-managerial evaluation of the decision.

Taking decisions without reference to a specific doxastic managerial system can be hazardous.

Reporting the results of any action of organization and management to the structures from the doxastic managerial system in which it competed in obtaining in a successful outcome would increase the chances of future imposed results by adopting some decisions based on variables that contribute to their success.

The systemic perspective helps to explain the maximum complexity and dynamic doxastic managerial processes, whose meta-managerial essences can hardly be highlighted by other means of investigation.

Using the concept of doxastic managerial system we try to analyse the phenomenon of organization and leadership "as it is", in alignment characterized by credibility, as a set of elements in predictive interaction.

The concept of doxastic managerial system is the expression of a way of thinking the management of organization and leadership on metamanagerial bases. It provides a framework that allows to highlight the internal and external factors as an integrated whole, dominated by quasiquantifiable confidences.

Doxastic managerial system's content is used to explain the mechanism of manifestation of real life phenomena using unreality/areality, or as an operational mean to optimize managerial activity by building models based on systemic behaviour. [Gaf-Deac, 2013]

Doxastic managerial system is a projection area by which is delimited the field within which is investigated, through credibility, the objective process of organization and management, that is the objective, 

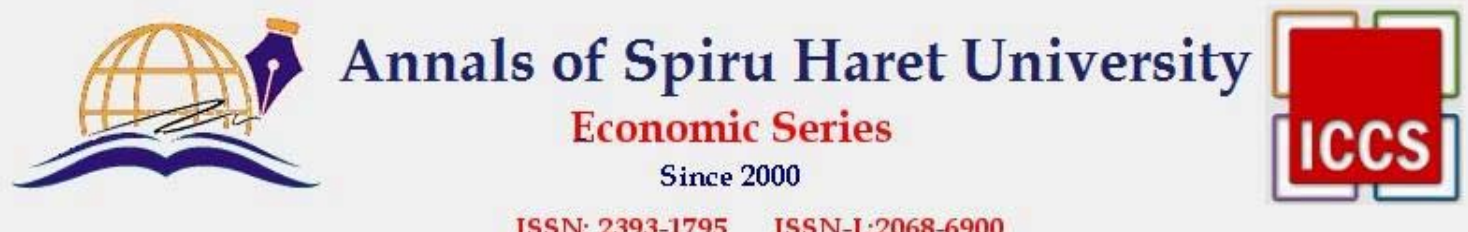

ISSN: 2393-1795 ISSN-L:2068-6900

\section{Issue 2/2016}

structural, spatial and temporal basis loaded with the objectified subjectivity.

The systemic doxastic frame of the management process puts in a new light not only the means used to improve the performance, management and prognosis, but also other aspects such as specific phenomena of selforganization and self-regulation, aspects regarding the creative manifestation of the individual in a group, explaining responsibility in the behaviour of subjects as social elements.

Within the concept of doxastic managerial system can be established the role to be played each element of the system (compliance of the functional destination of each component) and then the meta-managerial links that will be created in the system.

\section{Conclusions}

The concept of doxastic managerial system is the expression of a way of thinking the management of organization and leadership on metamanagerial bases. It provides a framework that allows to highlight the internal and external factors as an integrated whole, dominated by quasiquantifiable confidences.

- In relation to the environment, the doxastic managerial system appears as an inclusion and has at least an input, an output, a behaviour and a function that refers to confidence, conviction, good conventionality of an organization and/or leadership's acceptance.

- In management, doxometry gives the significant enlargement/wideness of the problematic of organizing and management, respectively the vision on the extreme limits for the actions of measuring the organization and management that may be of decisional interest.

- Doxometrics' object, scope and methods are subordinated to the derivation of the complex systems, respectively to establishing the decisional elements for behaviour management.

- Doxometric adjusting and, equally, estimating credibility represent searching procedures or instruments of the prediction alignments with higher degree of plausibility in organization and management. 


\section{Av Annals of Spiru Haret University \\ Economic Series \\ Since 2000 \\ ISSN: 2393-1795 ISSN-L:2068-6900}

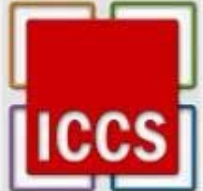

Issue 2/2016

Simplifying assumptions should not influence the growth trend of identifying managerial plausibility.

\section{References}

1. "DEX online", https://dexonline.ro.

2. "Merriam-Webster Online Dictionary", http://www.merriam-webster.com.

3. "Online Etymology Dictionary", http://www.etymonline.com.

4. A. Vanditti, "Indeterminancy and Endogenous Fluctuations in Two-Sector Growth Models with Externalities", Universite Aix Marseille III (1996).

5. D.J. Watts, Small World (New Jessey: Ablex Norwood, 1989).

6. I. Gâf-Deac, Bazele managementului doxastic (București: Editura Fundației România de Mâine, 2013).

7. M. Cozic, Logical Omniscience and Rational Choise, Department of Philosophy (Sorbonne, Paris, 2004).

8. M. Gâf-Deac and I.P. Roșca, Particularități regionale ale gestiunii corporative in România (Chişinău: Editura ULIM, 2014).

9. M. Gâf-Deac, Bazele practicii manageriale (Deva: Editura Infomin, 2011).

10. M. Gâf-Deac, Management corporativ (București: Editura Fundaţiei România de Mâine, 2014).

11. M. Gâf-Deac, Management general pentru economia bazată pe cunoaştere. Aplicații în sistemele productive operaționale (Deva: Editura Infomin, 2011).

12. M. Gâf-Deac, Management general. Teorie şi aplicații (București: Editura Fundației România de Mâine, 2008).

13. M. Gâf-Deac, Management general. Teorie şi practică (București: Editura Fundației România de Mâine, 2007).

14. M. Gâf-Deac, Management modern. Elemente de bază şi studii de caz (Bucureşti: Editura Fundației România de Mâine, 2005).

15. M. Gâf-Deac, Management operațional (Deva: Editura Infomin, 2011).

16. M. Gâf-Deac, Management. Baze generale şi legislative (Bucureşti: Editura Fundatiei România de Mâine, 2003).

17. M. Gâf-Deac, Managementul afacerilor (Bucureşti: Editura Fundaţiei România de Mâine, 2008).

18. M. Gâf-Deac, Managementul modelării structurilor tehnologice (Deva: Editura Infomin, 2002).

19. M. Gâf-Deac, Managementul producției (București: Editura Fundației România de Mâine, 2008). 


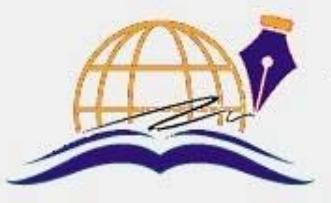

Annals of Spiru Haret University

Economic Series

Since 2000

ISSN: 2393-1795 ISSN-L:2068-6900

\section{Issue 2/2016}

20. M. Gâf-Deac, Teoria deciziei (Bucureşti: Editura Fundației România de Mâine, 2004).

21. M. Kocken, The Small-World (New Jersey: Ablex Norwood, 1989).

22. R. Audi and M. Setup, Doxastic Voluntarism and the Ethics of Belief (Oxford: Ed. NY, 2001).

23. R. Audi, "The Ethics of Belief. Doxastic Self-Control and Intellectual Virtue", Syntheses, no. 161 (2008).

24. R. Audi, Conceptele ştiinței (Bucureşti: Editura Academiei Române, 2010).

25. R. Carnap, Semnificație şi necesitate (Cluj Napoca: Editura Dacia, 1972). 